\title{
American Welfare Strategies: Three Programs Under the Social Security Act ${ }^{*}$
}

\author{
JOHN E. TROPMAN \\ School of Social Work, University of Michigan, Ann Arbor, Michigan 48109
}

\begin{abstract}
In the United States, a single piece of legislation, the Social Security Act, is the major vehicle through which the cash assistance to citizens is provided. This act contains many subprograms, programs so different in concept, administration and programmatic implication that many people do not know that the same piece of legislation makes them all possible. In this paper three programs-"social security," "unemployment compensation," and "public assistance"-are examined in a sociohistorical, sociocultural context. The roots of these programs are analyzed, their current operations outlined, and the policy problems currently confronting them are detailed. The ways in which the programs relate to the political mythology of the society is seen as important. Because of the continual conflicts arising out of the administration of public assistance, three special cases involving that program are mentioned.
\end{abstract}

\section{Introduction}

Paradoxical as it may seem, many people in the American and in the international community are not aware that the American national welfare structure is basically derived from programs made possible through a single piece of legislation, the act popularly known as the Social Security Act, and its amendments. One of the reasons this fact is not well known lies in the rather diverse nature of the programs, and the different political and programmatic evolution which has shaped them since their passage. This situation provides the policy and administrative scholar an opportunity to look at different approaches to providing social welfare benefits, and, in a global way, assess some of the differences in outcomes. One of the purposes of this paper is to undertake just such an analysis and assessment.

A second purpose, and one as important as the initial one, rests in an attempt to link the development of the different program modalities with different elements in the value structure of the social system in which they operate. Programs and policies

* Special thanks is due to Mrs. Shirley Roles, who made many useful conceptual and editorial suggestions. 
do not spring fully developed from some policy-making Zeus. Rather, they are the result of elements contesting in the social and political structure. Numerous studies link policy and administrative outcomes to rather specific near-term causes (Minister X hates Minister Y, etc.) (Lasswell, 1965; Ch. 1; Donovan, 1967). Yet too often administrative and policy scenarios are repeated with a completely different cast of characters, leading one to think that sets of predisposing causes are at least as operative as precipitating ones. And although we are using the area of income security and poverty relief specifically here, such an approach would be helpful in many different policy areas. Consider our national schizophrenia on the issue of alcohol problems, for example, which has led to two constitutional amendments. Understanding the cultural matrix is crucial for policy analysis.

\section{A Social-Historical Overview}

A detailed social-historical account of poverty relief remains to be written (Klebaner, 1964). But it is possible to outline some of the key elements in the political culture which any income relief or assistance program would have to take into account.

\section{Three Hundred Years of Hostility}

Perhaps most salient here is the fact that the poor have been the object of unremitting hostility for several hundred years. In England, getting the poor to work was a central policy concern. (DeSchweinitz, 1943) Work, good for both society and the soul, was a central feature of hatred of the poor. Somehow, it was felt that they were lazy and would not work. In the United States, one of the first instructions of the Massachusetts Bay Company (1629) was that:

Noe idle drone bee permitted to live amongst us, which if you take care of now at the first to establish, will be an undoubted meanes, through God's Assistance, to prevent a world of disorders and many grevious sins and sinners (Bruel and Wade, no date).

The English Poor Law Reform of 1834 did nothing to change this attitude. Generally viewed as a repressive law, it established the principle of "less eligibility," which specifies that any person receiving assistance ". . shall not be made really or apparently so eligible as the situation (i.e., position or station) of the independent laborer of the lowest class" (DeSchweinitz, 1943, p. 123). In practice, this has come to mean that any money grant has to be below the lowest wage. At that time, the poor were sent to workhouses. Though old, the issue is not dead. A recent study shows that less eligibility still operates here in the United States (Tropman, 1975). The reform also argued that not only poverty was bad but pauperism, or the taking of help for being poor, was also bad. The poor were thus doubly disliked, for being poor and for receiving help.

The importance of work seems to be crucial. It appears that the only government aid program which engenders acid hostility is public assistance-where people do not work or have some excuse (illness, for example) which is acceptable. A Report of the Illinois Legislature says:

The cold, hard fact of life is that man works out of necessity. Man does not work because he likes work but because he has to work. ... If the government is going to feed, clothe, 
provide a home and fire without the necessity of work, many people won't work. It's that simple (Illinois, 1963).

\section{The Pierce Veto}

In England, the central government had taken some responsibility for the provision of relief, but in America, under the Federal system, this responsibility was left to the states. There was a strong feeling that what little relief would be given should be completely a local responsibility. The reluctance to have any responsibility for social welfare's devolution upon the Federal Government became clear to Dorothea Dix in 1854. She had successfully convinced many state legislatures to make state provisions for the mentally ill. On the crest of this success, she almost single-handedly convinced the Congress of the United States to pass such a bill. This bill provided land which could be used to build mental hospitals. In a famous veto, President Franklin Pierce commented:

It cannot be questioned that if Congress have the power to make provision for the indigent insane without the limits of this District, it has the same power to make provision for the indigent who are not insane; and thus to transfer to the Federal Government the charge of all the poor in the States (Bruel and Wade, no date, pp. III-D1).

The Federal Government would not in fact enter the social welfare field until the 1930s. It is a credit to the prescience, if not the judgment, of President Pierce, however, that he correctly foresaw the route events would take.

Thus, in the 18th and 19th centuries the climate toward the poor was not sympathetic; it was harsh and judgmental. Titmuss has referred to this attitude as "metaphysical individualism." White and Fine have referred to the prominence of the "laissez faire" concept (White, 1958, p. 3; Fine, 1955). To be in need was the individual's own fault; society would help only in the most extreme cases.

\section{Private Charity}

To suggest that there was a generally hostile attitude is not to imply that nothing was being done to help. The predominant norm prevented government from taking much responsibility; and certainly anything more than minimal was too much. This situation pushed development of relief programs into the private sector. Thus, special agencies for the poor developed in the private rather than the public arena. With this location of help, there also developed a group of people helping the poor; friendly visitors who saw themselves as having a vocation rather than being government employees. Both factors have had a lasting impact on social welfare. It set the precedent that the poor need individual attention from individual persons, as well as money, and became the tradition out of which one of the Social Security Act programs - public assistance-justified its concept of caseload. In the United States, the private sector had, until the depression, the primary responsibility for programs of poverty relief. 1

\footnotetext{
${ }^{1}$ By responsibility I do not mean that they were the only group providing money. The government was providing cash. In 1890 , the social welfare expenditures were $2.4 \%$ of the gross national product ( $\$ 318$ million of expenditures). By $1969 / 70$ this proportion had risen to $15 \%$. Rather, the private agencies were dominant in their conceptions of poverty causes and cures, and in the public eye. (Source: Social Security Bulletin, December, 1970, p. 4.)
} 


\section{The Depression}

During the 1930s, the depression put such stress on private agencies' resources that there came to be a general feeling that something else should be done for those in need (Angell, 1936). The Federal Government, under President Roosevelt, was receptive. Politically, however, several developing strains of thought had to be harmonized in any legislation. First, there was the notion that specific groups of people were "deserving" of aid. Second, there was the idea that it might be possible to "insure" against such disasters like losing one's job, or that one could insure against poverty in old age by paying in a little over a lifetime, like an annuity. Third, there was the group of charitable workers who had been heavily responsible for poverty relief since the late $1800 \mathrm{~s}$. Their concepts of the causes and consequences of poverty, and the appropriate structure of relief, could not be ignored. As it turned out, it appears their ideal was to create, through governmental action, a sort of giant private social agency, which would operate much like the social agencies of that time but with vastly augmented resources. And finally, there was the Federal system itself. Somehow, an accommodation had to be made between state and Federal interests.

\section{The Social Security Programs}

In this nexus of pressures, then, the Social Security Act was passed (P.L. 271, 74th Congress; approved 8-14-35; 49 Stat. 620). With its passage the Federal Government took on the responsibility of providing security against economic hardship for some designated groups of Americans. Such security was not to be provided in a single program, however. The climate of American opinion surrounded poverty, especially the Federal Government's responsibility concerning poverty, was too unfavourable to permit the "Family Allowance" plan being considered as in other countries. There was not the deep concern for social factors producing poverty which was to find its expression (and a set of proposed solutions) in the Beveridge report in England (Friedlander, 1958, pp. 47-48). The American strategy was to make the poor "eligible" by categories. The strategy of the category system was to designate certain groups of needy for special legislative attention.

In the act three basic programs were developed to meet the need for help and economic security. ${ }^{2}$ The first two programs are "insurance" programs, for which a special tax is levied. The third program is a collection of various "assistances"called the Public Assistance Titles. As we shall see, even the name makes a difference in the legitimacy.

\section{Social Security}

The Social Security Program (OASDHI) is one which provides a fixed money payment for Old Age, Survivors and Dependents of the Insured person, and also provides medical care for older people, and in some instances for others. The locus of administrative control in the Social Security program is in Washington. It is

\footnotetext{
${ }^{2}$ There is a provision in the act for a grant-in-aid program for child welfare purposes. We will not discuss that program here. An interesting study, done at the time of passage by an academic who later had important policy roles is Social Security in the United States by Paul Douglas (1936).
} 
a Federally administered program, and payments are made by Federal employees of the Social Security Administration.

The Social Security Administration is decentralized by region, by districts within each region, and through the use of field offices within these areas. While the Social Security Administration employee is a Federal employee, it seems that an organizationally localized professionalism has developed, similar to what happened in the Tenessee Valley Authority, and the Forest Service (Selznick, 1950; Kaufman, 1960). The growth of organization-specific techniques has been generated through inservice training, and is discussed in print (DeSchweinitz, 1961).

Over the years, social security has secured a place on the American scene for itself. It has not been under the same attack which has plagued the administration of public assistance, although recently, questions about its fiscal base have been raised. One reason for this relative freedom is, of course, its high quality administration. Policies are clear and are enforced across the board. A person is eligible for social security whatever his geographical location; there is no "residence requirement" as there was in the Public Assistance Program. The fact that it is a totally Federal program simplifies and consolidates the administration. Three other factors are important. First, everyone who is insured gets social security, regardless of his financial need. This provision has removed much of social security from the class of "aid to the needy" programs. A second and related feature of the program, which helps in the public relations, is that benefits have been determined on the basis of wage rate and on the number of quarters in which one was working under an insured occupational category. Thus, the benefits are tied directly to work. Finally, there is a special tax which Americans pay for social security, which is plainly marked on every pay voucher. This tax money goes into the Social Security Trust Fund, from which current benefits are paid. This trust fund supports the "insurance" concept and creates the image that "I have paid in, and I deserve to get it back." The aspect of insuranceindeed, the very name "insurance"-lends a legitimacy and aura of public acceptance to the Social Security Program.

However, in 1974, three programs previously thought of as "welfare" programs, Old Age Assistance, Aid to the Blind and Aid to the Permanently and Totally Disabled (O.A.A.; A.B.; and A.P.T.D.) were transferred to the Social Security Administration and are now administered there, under the title of Supplemental Security Income (S.S.I.). This transfer represents the first time that the Social Security Administration has administered a "means tested" program, and it has created some implications which can be considered later. Suffice it to say now that the program is Federally financed (as opposed to grants-in-aid to the states under the Public Assistance Administration) but the grants may be supplemented by the states either through the State Departments of Welfare or through the Social Security Administration itself. In the case of state supplementation, and many states have chosen to supplement, the amount is purely a state decision.

\section{Unemployment Compensation}

The program of unemployment compensation is administratively unique. Under Title III of The Social Security Act, the Federal Government collects a tax $(3.2 \%$ on 
the first $\$ 4,200$ of workers wages) based on the employers' "experience" with unemployment-the more a particular employer "contributed" to unemployment (i.e. creates unemployment), the more tax he has to pay. Unemployment Compensation is not, however, a Federal program. The law provides that if the state has an Unemployment Compensation Program, then it can secure a credit of up to $90 \%$ of the Federal tax. In effect, the law allows for a Federal Unemployment Compensation Program only if the state does not have one. The locus of control in the Unemployment Compensation Program is fundamentally in the states, with loose Federal supervision. The Federal law, administered by the Bureau of Employment Security in the Department of Labor sets up certain requirements which the states must meet if they are going to receive their rebate. These requirements are essentially:

1. The payment of benefits through a public employment office;

2. The deposit of state funds in an unemployment insurance fund managed by the Federal treasury;

3. The right of unemployed workers to refuse jobs which do not meet prescribed standards without having the benefits withheld;

4. The right of an unemployed worker to a hearing before an impartial tribunal if his claim for benefits is denied.

These requirements are broad ones, they permit some considerable difference between the states. Although benefits are supposed to be "adequate" for "a limited period," there is wide latitude in interpretation of these terms. This situation arises because each state has had to pass its own unemployment compensation law, and thus there is ample room for the play of state interests. Under Title IX of the Social Security Act, the Social Security Administration makes grants to the states for $100 \%$ of the administration of the program. Both the state administration, and the Federal responsibility for paying for state administration, create potential loci of friction between the Federal and the state levels (Haber and Murray, 1966).

While the specific titles of the Social Security Act make provision only for unemployment insurance, the program as it evolved has links with employment services. Haber and Murray note that:

When the Social Security Act was passed in 1935, the desirability of coordination of unemployment insurance and the public employment service was taken for granted and made a condition for states receiving Title III grants (Haber and Murray, 1966, p. 419).

Thus at the state level, two services are provided, employment counseling as well as an unemployment benefit. Thus state employment service workers, like public assistance workers, have a counseling job to do, but they have, like Social Security Administration workers, an insurance program to administer. They have not developed the bureau professionalism of the Social Security Administration, nor the identification with an outside profession (social work) of the public assistance workers.

\section{The Public Assistance}

The third set of programs funded under the Social Security Act is that called Public Assistance. Initially, there were three programs-Old Age Assistance (OAA), Aid to 
the Blind (AB), and Aid to (Families With) Dependent Children (AFDC). In 1950, an amendment was passed which made provision for Aid to Permanently and Totally Disabled (APTD). The act provides that out of general revenue funds the Federal Government will make public assistance grants-in-aid to the states designed to help with the kinds of problems suggested here. It is a mutually contributory program; the states make only small contributions to each program, and the Federal Government is footing much of the bill. Since these categorical programs do not cover the many situations which can place persons in financial need, there is a program of General Assistance funded out of state and local funds to fill the gaps. ${ }^{3}$ To qualify for aid, each state must submit a "state plan" as provided for in the Social Security Act to the Social and Rehabilitation Service, Department of Health, Education and Welfare. The plan must be in conformity with the act and subsequent interpretations at the Federal level. Remuneration is made to the states in two parts. One type of rebate is for the actual grants made to clients. A second rebate reimburses the state for personnel costs, since certain types of personnel, and certain client/personnel ratios are encouraged or required.

If the state plan, or state action as it turns out, is not in conformity with Federal law and interpretation, then the grant-in-aid funds may be withheld by the Federal Government. This step is a serious one, and has only occurred in a few instances. In at least one case (the "Jenner Amendment" controversy) the law was changed to permit a state to do what it wished.

Just as for the Unemployment Compensation Program, there are sizeable state administrations for public assistance, since the Federal Government itself does not make any payments directly to individual citizens. Basically, two forms of assistance administration are used. In one method the state is the actual agent, and sets up field offices around the state. In the other method, the county acts as the agent, under supervision by the state.

As in the Unemployment Compensation Program, two services are given-financial help in the form of grants, and "services" in the form of personal counseling. In the Unemployment Compensation Program the counseling usually takes the form of assistance in seeking and securing a job. In the Public Assistance Program, there is an attempt to make the services "professional" in a social work sense, and counseling may range over a broad variety of personal topics. Every "client" is assigned to a caseworker. However, the concept of services and payments, developed recently, divided workers into "service" and "assistance payment" workers.

The arrangements of these programs have now changed. Under recent revisions, the Blind, Disabled and Aged Programs have been moved over to the Social Security Administration, leaving Aid to Families with Dependent Children as the single public assistance. ${ }^{4}$

\footnotetext{
${ }^{3}$ It should be emphasized that "General Assistance" is not a Federal Program, nor does it receive any assistance from the Federal Government.

${ }^{4}$ There is not, however, completely firm agreement on the programs to which "assistance" refers. I am using it to refer to the program with that title. Others, however, would argue that SSI is a public assistance, even though it is now within the administration of the Social Security Program. I am not including other types of payments, such as medical payments here either.
} 


\section{Policy Problems in Income Relief Programs}

As might be expected, each of the programs has a set of policy problems unique to it. Basically, in each case, these problems have to do with coverage, and benefit levels. However, the Public Assistance Program is somewhat unique in this regard because it suffers from a crucial lack of public confidence and from a public hatred of its personnel, which undermines its own efforts.

\section{Social Security Policy}

The first questions of policy which are involved in the administration of social security are of two kinds - (1) what shall be included within the scope of the program, and (2) how shall internal administrative arrangements be set up. Regarding the latter, perhaps the more minor issue, the questions about the proper mechanisms to maintain uniformity through the fields offices are prominent. These have been solved, to a degree, through multiple supervision and functional decentralization (Davis, 1950, pp. 298-299).

The more serious policy issue relates to the kind of programs and the kinds of people involved in social security. Social security coverage has been continually broadened. The occupations covered have also broadened. The important question is, "Should everyone be covered, and, if not, where should we stop." The coverage has now become quite broad. It is perhaps a measure of the progress of the Social Security Program that a new set of crucial policy issues confronts it now. Basically, these new issues are: (1) a crisis in confidence about its fiscal integrity; and (2) the administration of a means-tested program.

In recent years, the social security payroll tax, which used to be quite minor, has climbed to a total of $11.7 \%$ of salary, half paid by the employer and half paid by the employee, to a limit of $\$ 15,300$. These amounts are definitely not trivial, and have brought increased scrutiny to the Social Security Program.

The potentially onerous level of the current tax is brought into sharper relief by the discovery that the Social Security Trust Fund will have more claims than funds, if current rates of expenditure are maintained with no increase in income. This "cash flow" problem results from both increased benefits packages and increased numbers of claimants. Either the tax rate will have to be raised, or the upper limit on income taxed will have to be raised, or the Federal Congress will have to supply some General Revenue Funds or some combination of the above alternatives will have to be developed to take up the slack. Whatever the alternatives chosen, social security will be more criticized and investigated than ever before (Richardson et al., 1975).

The addition of the SSI program (paid for by General Revenue) has created a different type of crisis. While the fiscal crisis was external, the SSI crisis is internal, internal in the sense of staff. The Social Security staff hitherto have never administered a means-tested program. It has proceeded smoothly in Michigan, but has tested a staff basically trained in an orientation which is not one of meeting "need" (Bernard, 1975).

And the "need-based" addition to the social security system may, in time, become an external matter if it erodes the omnibus image that the country holds of the program. 


\section{Employment Compensation Policy}

Policy issues in the unemployment compensation program are also complex in nature. Essentially they relate to the level of payment and the nature of the experience rating. Many people believe the levels of payment should be raised. William Haber concluded that only Federal legislation will help.

And it is clear, after many years of exhorting the states to increase their maximums, that no amount of urging by high officials of the Federal Government or anyone else is going to raise maximum benefits. ... It is clear that the maximums will be raised to adequate levels only if a minimum Federal standard is enacted (Haber, 1965).

A second issue relates to the "experience ratings" provision, in which an employer is charged a tax on the basis of the amount he "contributes" to unemployment. Since this amount is determined by the number of people (his ex-employees) who are drawing unemployment compensation, there is much to be gained by a challenge. It would probably pay a large corporation to have lawyers challenge claims to unemployment compensation. Any claim which is disallowed is thus a reduction in the employer's "contributions" to unemployment (experience rating) and, hence, to this tax. The "experience rating" structure which was set up under some kind of "fair share" idea, has resulted in continual challenge by some employers to the claimant, independent of the claimant's particular justification. And while this procedure may be judicially a fair one, it is also a time consuming and expensive one for both employer and employee. And because of different employment patterns in different industries, there is a question raised about the experience rating concept itself.

These issues are not the only ones. There are questions about the level of tax, the base which is taxed, the length of time benefits should be given, the relationship between employment counseling roles and unemployment compensation roles within the state Employment Security Commissions, to mention a few. Yet overall, it appears fair to conclude that the program has more support than the Public Assistance Program.

\section{Public Assistance Policy}

Public assistance policy represents perhaps the most complex area of the three programs. Much of the onus distilled from the historical climate devolves on this program and the administrators must cope with not only the usual run of administrative problems, but also with the extra and special problem of public hostility and distrust. This negative public attitude not only augments the usual difficulties, but creates special and unique ones.

\section{State Plan}

Routinely, the public assistance administration has state issues to consider. As an intergovernmental program, issues of intergovernmental relations are always present. State and Federal government do not agree, and this is often reflected in controversy around the approval of the state plan (Bureau of Public Assistance, 1953). And since 
the state has to make a regular appropriation to cover its share of the assistance budget, the assistance program comes in for regular review in each state legislature. This review would be pro forma or minimal in many cases, but in the case of assistance, the undercurrent of public distrust and hostility has this regular opportunity to surface.

\section{Staff}

Another regular source of difficulty lies in the staff area: who are appropriate staff, and what is their role. These questions involve issues of professionals versus nonprofessionals. Assistance operates, as was mentioned, on a caseload concept. It was assumed, and was encouraged, that the caseworkers be people with MSW degrees. However, the arithmetic is such that there can never be sufficient MSW persons to handle the public assistance caseload. Many of the personnel are nonprofessionals.

In 1965 there were 35,000 public welfare workers. Of this number, 1,500 have professional degrees and are members of the professional association. While this is a minority estimate because there are likely persons who are trained but not members of the professional association, it nevertheless presents a picture of the general relation (Morris, 1965).

Indeed, the problem of sufficient "professional staff" is as old as the profession. Lewis reports in the Encyclopedia of Social Work that in 1893 only the Boston, Baltimore and Brooklyn Charity Organization Societies were able to assign friendly visitors to a significant proportion of cases (Lewis, 1971).

Social workers also have clung tenaciously to the belief that more MSW workers would help reduce the rolls. There is not only no evidence on this point, but as it turned out, the assistance rolls were so far below poverty levels that increases were almost inevitable. In any event, having made the claim, social workers were not able to "deliver" lower rolls, and are now regarded suspiciously by state and federal legislators.

\section{Service v. Payment}

The professional-nonprofessional issue is linked to another policy issue: the nature of the service required for assistance recipients. Social workers generally were identified with a "service" view of assistance, in which the primary goal was personal counseling, and financial assistance was a "means to an end." Nonprofessionals were identified with the posture that money payment was all that was necessary, and one became involved in personal problems and difficulties only if absolutely necessary. However valuable and important the distinctions here, neither group fell fully within those limits. However, the identifications stuck in the public mind, and legislators are now saying that "high cost" professionals are not needed to give "service" of an amorphous sort to a continually changing group of clients. Influenced perhaps by the style of administration in social security and unemployment compensation, Congress has moved to separate income support from "service," to separate income support services from counseling services. However, it appears that the problems do not fall into easily separable categories, and tension has been created between "payments" employees (who tend to regard themselves as somewhat lower on the organizational status ladder) and "social services" employees. 


\section{Cheating}

These regular administrative problems have an overlay within the system resulting from negative public attitude. People in general appear to be convinced that those who receive aid are cheating. Overall, the level of cheating is about $4 \%$. Williamson, in his study of attitudes toward the poor, found that his respondents believe that $41 \%$ of the recipients lie (Williamson, 1974). In state after state, investigation after investigation goes on to find and reduce the number of people who are receiving public aid illegally. Things reached a low point in the "midnight search" program in California which created a public furor. Investigators were sent out in the middle of the night to inspect the homes of Californians who were receiving AFDC, to search for men (Reich, 1963).

\section{Rise in Rates}

During the period of the $60 \mathrm{~s}$, rates of welfare use rose dramatically (Tropman, 1975). Between 1966 and 1971 , the cases per 100 families rose from $2.4 \%$ to $5.6 \%$, an increase of $133 \%$. The caseload rise led to increased criticism of the welfare system, and at least one major interpretation of the function of welfare as responsive to the urban riots. Welfare, Piven and Cloward argue, serves to keep the urban masses from full revolt (Piven and Cloward, 1971). However, in all the discussion about the rise in rates, two points are usually overlooked. First, there has always been a substantial gap between the program enrollees and the total number of people who might be eligible. One of the reasons that rolls can grow so rapidly is that persons who would be entitled to benefits, but have not applied for them, have begun making application. Second, while costs have indeed increased, the "value" of the average grant, taken as proportion of the per capita income in the state in that year, has decreased (Tropman and Gordon, 1974).

\section{Welfare Rights}

One feature which accounts for the apparent increased willingness to apply, and has been an important psychological as well as political factor is the development of a welfare rights organization. Welfare benefits have been one of the few areas of our society in which the actual beneficiaries are not organized to press for more and better benefits. Given that American society is almost characterized by such "interest groups," this omission is of interest. But in "the egalitarian decade" of the $60 \mathrm{~s}$, the rights of many groups who suffered from discrimination of one sort or another were pressed. In the welfare case, the group support for application, the sense that one was simply exercising a right rather than abusing society's generous impulses was surely an important factor. And for the first time, a group of welfare users (the clients) was available to make policy inputs along with the traditional group of purveyors (social workers, the American Public Welfare Association).

\section{Three Incidents in Assistance Administration}

It might be useful to describe some of the special problems in the administration of assistance through some incidents which have brought the Federal Government into 
conflict with a state administration. Three cases will be illustrative-the so-called "Jenner amendment" case, the "suitable homes" provisions, and "Title XX."

\section{Jenner Amendment}

In the Jenner amendment controversy, the central issue was whether or not a state could publish the names of the people receiving relief (Cohen and Berman, 1952). Such a publication had been against the law since the 1939 amendments to the Social Security Act (p. 1, 379, 76th Congress). The legislature of the State of Indiana passed an act which allowed this to be done, and hence did not conform to the Federal Statute. Funds were withheld from Indiana. While Indiana passed the bill, other states had not been idle, though they did not go as far. The state legislatures of Georgia, Illinois, Florida, Oklahoma, and Alabama urged Congress to repeal the section of the Social Security Act which forbade the publication of names. Several bills were introduced to this effect, including one by Representative Reed of New York State and one by Representative Harrison of Virginia. They did not pass. Senator Jenner attached a rider to the appropriations bill for the Federal Security Administration (the early name for the Department of Health, Education and Welfare) but it did not pass. Finally, a 1951 conference committee included the amendment on a minor tax bill. All it said was that a state should not be refused money for making public the names of relief recipients. The Federal Government had lost.

Several of the public attitudes mentioned are active here. The basic public attitude which permitted the Federal Congress and the various state legislatures to act as they did must be noted. Apparently it was an attempt to shame the recipients of relief into getting off the rolls. Again we see the public and the legislative bodies making the assumption that people are cheating, and that unless they are exposed to public shame, they will not get off the rolls. The Federal Administration took the view that the names of recipients should not be revealed-a position in accord with social workers' views of the matter-but lost.

This incident points out the difficulties in the Federal enforcement of standards in the states. If the states feel strongly enough, it is probable that the enabling legislation will be changed to the detriment of Federal standards. Of course, this kind of problem can come up only when there are specific Federal standards to meet, as in the case of grants-in-aid for public assistance. The standards in unemployment compensation, for example, are too broad and diffuse to permit much Federal enforcement. I know of no case where funds for unemployment compensation have been withheld.

It should be noted, however, that this conflict was not one of Federal Government versus state government, as such. The state administrators in Indiana were not particularly happy about the turn of events. They themselves were not in favor of opening the lists to public inspection. What actually is involved here is a "government versus the public" controversy, which results in part from the "bad press" public assistance has. From this point of view, the administrators are very vulnerable to public attack. For example, Senator Byrd (D-Va.), "shocked" to hear about a number of persons on public aid in Washington, D.C., who were not technically "eligible," 
instituted a "crackdown." Children in families which were refused grants wound up in an overcrowded home for children (Anderson, 1965).

\section{Suitable Homes}

These cases were not the only ones to come up. There is the so-called "suitable homes" case in Louisiana. A state law was passed providing that any woman who had an illegitimate child while on relief (AFDC) must prove that she was maintaining a "suitable home" to remain eligible. Grants to such women were terminated and they had to reapply. Although this provision received unfavorable editorial comment from the New York Times, and the Chicago Sun-Times, the Secretary of Health, Education and Welfare did not find the state law incongruent with the Federal requirements. At one point, up to 2200 children were affected.

The fear that there are "men in the house" of women on relief, breaks out in another case-the California inspection case. In the State of California, midnight and early-morning raids had been ordered on the homes of ADC recipients, to ascertain whether or not a man was in the household. Social workers covered the front and back doors of the dwelling, to prevent the man from escaping, should one be present. This procedure brought a rash of protests and resignations. One scholar adjudged it to be unconstitutional (Reich, 1963). Although the raids are in abeyance, the issue of the right to engage in such activity has never been settled.

Finally, there are the myriad of local cases in assistance which become grist for the local press. One stalwart in Illinois recommended that the poor in Chicago be sent downstate to farms owned by the state, where they could grow their own food and learn to spin their own yarn for clothes (Anonymous, 1963). This plan does not seem to be much of an improvement over the Nichols plan, advocated in 1932, under which restaurants would dump uneaten food into five-gallon containers, for which the poor would be eligible by chopping wood donated by farmers (Schlesinger, 1958, p. 172).

\section{Title XX}

Some of the problems in Federal-State relations were thought to be solved as well as some loopholes in the Federal law plugged by the most recent addition to the Social Security Act, Title XX. This title provides money to the states for services. States must provide a plan for such social services, but the plan is not reviewed for content by the Federal government; it is only viewed with respect to its conformity to certain present categories (so much service must go to people receiving welfare payments, for example). Further, and unlike the provision in the 1962 amendments to the Social Security Act, it sets a total national maximum ( 2.5 billion) for social services spending, and sets a share for each state according to its percentage of the national population. Previously, Federal reimbursement had been open-ended, in the sense that the Federal government was required to match what each state spent in this area according to Federal formula(s), but the definition of what constituted services was very broad. In at least one way, this new title seeks to reduce Federal-State conflict and limit spending (through the national ceilings) without the Federal government becoming deeply involved in arguments with the states over what constitutes "service" to clients. 


\section{Policy Issues and Implications}

Considering the three programs individually and within the historical context makes possible a greater understanding of some of the problems and difficulties faced by these programs. It is immediately clear that, for historical and sociopolitical reasons, the insurance concept is much more acceptable, and its administration much more tranquil, than the concept of "public assistance" and its administration. This conclusion does not rest on an analysis of these three programs alone. Other programs for the "poor" have suffered much the same difficulty as the public assistance program. An early version of the Office of Economic Opportunity Program ("the poverty program") was developed in the 1930s and has now virtually gone out of existence (Baldwin, 1968). And the modern "poverty program" rose and fell within four years. Hence, successful policy in the area of income and poverty relief must take these events into account. If not, it is likely that future programs to aid the poor in the United States will suffer the same fate as the predecessor programs. It is not, however, exactly clear what "taking these events into account" would entail. Certainly we would be on relatively safe ground concluding that the insurance approach has more general public support. However, second thoughts indicate that the "insurance" approach also contains, and not by necessity, a benefit and allocations pattern which does not respond to the level of individual need. If one is eligible for OASDHI, one's benefit amount is determined not by need, but by whatever category of eligibility is appropriate. The same is true for unemployment compensation. We might, therefore, tentatively note the possibility that it is nearly universal coverage which is the important element, along with the insurance feature. It may be that the only way middle-class antagonism toward the poor can be muted is to include both groups in a benefit package in such a way that reduction of the benefits to the poor reduces benefits to the middle class as well. Additional explorations of the source of middle-class hostility, historically and contemporaneously, toward the poor may suggest more sophisticated alternatives.

In terms of policy making, then, how does the government proceed? The answer to this question depends in part on the point of view. One sanguine opinion points to two ways in which the Social Security Board has proceeded to make policy. Hale argues that the board had three principles (Hale, 1957)

1. That states should actually be involved in building Federal policy;

2. That policy must be based upon "facts";

3. That policy decisions must be made known to all concerned.

He further argues that the Social Security Board uses either a "common law" approach, or a "case approach" in coming to a decision. The implication of the presentation is that the policy making approach is decidedly a nonpolitical one, with the "facts showing clearly what decision should be made."

Such a placid approach is not the only characterization available, however. Leon Lefson talks about the development of the Aid to the Permanently and Totally Disabled in California in decidedly political terms (Lefson, 1966). He feels that four factors influence the administration of a new law: 
1. The political climate when the law was passed;

2. The way the administration (both state and local) interprets that climate;

3. The nature of the relationship between the administration and the policy making board;

4. And, for states which use the county form of assistance administration, the strength of the county supervisors.

I would tend to agree with Lefson. While I would not wish to discount the importance of the attempts to keep the administration nonpolitical, it is my conclusion that a political calculus always enters into the administrative calculus. An administrator cannot go ahead and develop policy with no regard for its political implications; he may soon find himself without funds. Especially in the administration of public assistance, the political aspects of the administration come to the fore because of the relative lack of public sympathy for program goals.

In this paper, then, we have attempted to suggest three very different types of administration which have developed to administer the programs under the Social Security Act. Each has its problems and its advantages, but we have emphasized how the grant-in-aid program makes control by the Federal level difficult, and often tenuous. The differences in administration have in part been explained by the different political climates surrounding the programs, and by the differing degrees of public acceptance and support which they enjoy. Other differences in professional staffing and interrelationships were suggested. Perhaps the most important conclusion one could draw from this comparative approach, for welfare administration as well as for other forms of administration, is that there are many ways to organize a program, and that an important part of the ultimate success of the program will depend upon these initial organizational forms. However, from the point of view of policy formation, the question of how the organization should be set up is often a difficult one, with important political overtones. One ignores these overtones at his peril.

\section{REFERENCES}

Anderson, J. W. (1965). “A Special Hell for Children in Washington,” Harper's 231: 1386 (November).

Angell, R. C. (1936). The Family Encounters The Depression. Gloucester Mass.: Peter Smith. Anonymous (1963). "Public Assistance in The Headlines," Social Service Review Vol. 37, 2 (June), 212.

Baldwin, W. (1968). Poverty and Politics: The Rise and Decline of the Farm Security Administration. Chapel Hill: University of North Carolina Press.

Bernard, G. The SSI Commission in Michigan. Lansing: Dept of Social Services.

Bruel, F. and Wade, A. (n.d.). Readings in Social Welfare Policy and Services, Vol. 1. Chicago: School of Social Service Administration.

Bureau of Public Assistance (1953). Characteristics of State Public Assistance Plans. Washington, D.C.: United States Department of Health, Education and Welfare, Social Security Administration.

Cohen, W. S. and Berman, J. (1952). "Safeguarding the Disclosure of Public Assistance Records: The Legislative History of the 'Jenner Amendment', Section 618, Revenue Act of 1951," Social Service Review, Vol. 2 (June), $229-234$.

Davis, J. A. (1950). Regional Organization of the Social Security Administration: A Case Study. New York: Columbia University Press. 
De Schweinitz, K. (1943). England's Road to Social Security. Philadelphia: University of Pennsylvania Press.

De Schweinitz, K. (1961). Interviewing in Social Security. Washington D.C.: The United States Government Printing Office.

Donovan, J. C. (1967). The Politics of Poverty. New York: Pegasus.

Douglas, P. (1936). Social Security in the United States. New York: McGraw-Hill.

Fine, S. (1956). Laissez Faire. Ann Arbor: University of Michigan Press.

Friedlander, W. (1958). Introduction to Social Welfare, 2nd edition. Englewood Cliffs: Prentice-Hall.

Gordon, M. S. and Emerson, R. W. (1957). Unemployment Insurance. Berkeley: Berkeley Institute for Industrial Relations.

Haber, W. (1965). Testimony Given Before the House Ways and Means Committee at the Hearing on H. R. 8282 (The Administration Proposal to Amend Federal Unemployment Compensation Statutes). Unpublished manuscript, University of Michigan.

Haber, W. and Murray, M. G. (1966). Unemployment Insurance in The United States. New York: Richard D. Irwin.

Hale, M. P. (1957). "The Process of Developing Policy for A Federal-State Grant In-Aid Program, as Illustrated by the Work of the Social Security Board: 1935-1946," Social Service Review Vol. 31 (September).

Illinois, State of, (1963). Report of the Legislative Advisory Committee to the Illinois Public Aid Commission; Report to Governor Otto Kerner and The Members of the 73rd General Assembly.

Kaufman, H. (1960). The Forest Ranger. Baltimore: Johns Hopkins Press.

Klebaner, Benjamin, (1964). "Poverty and it's Relief in American Thought," Social Service Review.

Laswell, Harold (1965). Psychopathology and Politics. New York: Free Press.

Lefson, Leon (1962). "Critical Decisions in a Public Welfare Program," Social Service Review Vol. 36, 1 (March).

Lewis, U. (1971). "Charity Organization Society," in Encyclopedia of Social Work, p. 97. New York: NASW.

Morris, R. (1965). "Editorial," Social Work Vol. 10, 4 (October), 2.

Moynihan, D. (1969). Understanding Poverty. New York: Basic Books.

Piven, F. and Cloward, R. (1971). Regulating the Poor. New York: Pantheon.

"Public Assistance in Headlines," Social Service Review Vol. 37, 2: 212.

Reich, C. A. (1963). "Searching the Homes of Public Assistance Recipients: The Issues Under the Social Security Act," Social Service Review Vol. 37, 2 (September).

Richardson, E. et al. (1974). "Social Security," Journal of Social Welfare Vo1. 1, 3.

Schlesinger, A. M., Jr. (1958). The Crisis of the Old Order. Boston: Houghton Miffin.

Selznik, P. (1950). T. V. A and the Grass Roots. Berkeley: University of California Press.

Titmuss, R. M. (1959). Essays on the Welfare State. New Haven: Yale University Press, p. 20.

Tropman, J. E. (1975). "The Welfare Gap," Journal of Sociology and Social Welfare 2, 4 (Summer).

Tropman, J. E. and Gordon, A. (1974). "The Welfare Threat." Unpublished manuscript. The University of Michigan.

Truman, D. (1958). The Governmental Process. New York: Alfred Knopf.

White, L. D. (1958). The Republican Era. New York: Macmillan.

Williamson, J. (1974). "Beliefs about the Welfare Poor," Sociology and Social Research 58 (January). 